\title{
A casa (entre)aberta
}

\author{
Ana Alice Bueno \\ Universidade Federal de Santa Catarina
}

\section{Introdução}

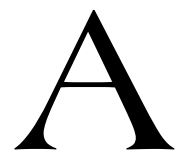

típica família brasileira dos meados do século XVIII e XIX era fundada sobre um poder patriarcal, baseado na moral cristã e alicerçada numa economia basicamente rural. Mas, essa realidade começou a mudar a partir do século XIX, quando o domínio patriarcal começou a decair e os burgueses e comerciantes ascenderam socialmente, fundando, assim, a cidade. Gilberto Freyre é um dos escritores mais lúcidos que recolhe e analisa dados da formação e transição da sociedade brasileira, especialmente em Sobrados e mucambos, obra datada de 1936.

$\mathrm{Na}$ ficção brasileira, Lúcio Cardoso retrata em Crônica da casa assassinada (1956) a atmosfera da já decadente família patriarcal dos Meneses, que tenta manter a Chácara onde vive, em Vila Velha (MG), mesmo sendo visível a decadência, observada pela pintura desgastada do casarão, pela falta de manutenção nos jardins e pelas dívidas acumuladas.

(...) a casa está caindo aos pedaços há tanto tempo! (representamos) uma família arruinada do Sul de Minas, que não tem mais gado em seus pastos, que vive de alugar esses pastos quando eles não estão secos, e não produz nada, absolutamente nada para substituir rendas que se esgotaram há muito. (...) Devemos aos empregados todos, à farmácia, ao Banco do povoado... ${ }^{1}$

Em ambos os autores é possível observar uma mesma ótica sobre a família, no sentido de abrir as portas dos casarões para que os leitores observem os costumes, hábitos e segredos, germinados e alimentados pela moral, sobretudo, cristã, muito forte à época dos meados do século XIX.

${ }^{1}$ CARDOSO, 1963, p. 51-52. 
Há uma aproximação temática - a família patriarcal - entre Gilberto Freyre e Lúcio Cardoso, o que permite contrapor essas escrituras no sentido de perceber as representações possíveis que alguns tópicos descritos por Freyre podem ser encontrados na obra de Lúcio Cardoso, tais como:

- A decadência do sistema de família patriarcal e ascensão do urbano (em Sobrados e mucambos), representado pela personagem urbana de Nina em relação aos moradores e à Chácara dos Meneses (em Crônica da casa assassinada);

- A dialética da orientalização x ocidentalização (em Sobrados e mucambos), em contraponto com os ambientes e essas influências/presenças na Chácara dos Meneses (em Crônica da casa assassinada);

- As narrativas (de memória): cronológica e histórico-social de Gilberto Freyre, e a que poderíamos considerar estelar (apontando para vários eixos) em Lúcio Cardoso.

\section{A presença erótica da cidade no ambiente rural/ patriarcal da Chácara dos Meneses}

A casa, o tipo de habitação, sabe-se que é uma das influências sociais que atuam mais poderosamente sobre o homem. Sobre o homem em geral; mas, em particular, sobre a mulher, quase sempre mais sedentária ou caseira. Especialmente dentro do sistema patriarcal, inimigo da rua e até da estrada, sempre que se trate de contato da mulher com o estranho. ${ }^{2}$

A partir dessa citação, a respeito do lugar da mulher na casa patriarcal, é possível imaginar o rompante que causa uma mulher oposta à caseira, uma mulher "da rua". Assim é representada a personagem Nina, da Crônica da casa assassinada, que após efetuar matrimônio com Valdo Meneses, no Rio de Janeiro, onde o conhecera, vai hospedar-se no seio familiar de seu esposo, ambiente muito distinto do que ela conhecia. Nina sai da cidade grande para o interior de Minas, um lugar rural e estritamente reservado; uma chácara particular, longe de qualquer comércio ou vizinhança.

${ }^{2}$ FREYRE, 1977, p. 152. 
Lugares/construções desse tipo preservavam as mulheres e guardavam os valores das casas-grandes brasileiras. Nina, como é de se imaginar, não se adaptou à vida reclusa na Chácara. No Diário de Betty (II), capítulo 9 da Crônica, a governanta descreve que:

Desde que ela chegou, não temos mais um minuto de sossego. A todo instante quer alguma coisa e nunca está contente, queixando-se dos empregados, da casa, do clima, de tudo enfim, como se fôssemos culpados do que lhe acontece. (...) Indaguei a ela para que tantos vestidos, se tinha intenção de usá-los todos. E acrescentei: 'Aqui em casa saem tão poucas vezes!' Ela me respondeu com irritação: 'Que me importa se nesta casa saem ou não? Farei exatamente o que eu quiser.' E indagou-me em seguida se não havia divertimentos na cidade, bailes, teatro, reuniões de qualquer espécie. Não pude deixar de rir, enquanto retirava da mala aquela quantidade de capas e vestidos. ${ }^{3}$

No capítulo 7 da Crônica, intitulado Segunda Narrativa do Farmacêutico, há a narração sobre as especulações a respeito da vinda de Nina à Chácara dos Meneses. Diz o farmacêutico que durante dias e dias a estação ferroviária

(...) viu-se cheia de gente à hora em que devia chegar o trem da capital. E essa expectativa transformou-se em fonte incomum de zunzuns e falatórios, quando ele [Valdo Meneses] regressou sozinho, após estada de vários dias na cidade. Diziam que ela não queria vir para a roça, e que detestava sair do Rio de Janeiro. ${ }^{4}$

Quando Nina, dias depois, chega à estação, "àquela hora completamente vazia. Dir-se-ia que estivera apenas deixando o interesse em torno da sua pessoa esmorecer, a fim de poder chegar tranqüilamente", causa indagaçôes e fascínio, pois vinha da capital do país para abrigar-se no lar da tão famosa família Meneses; além de ser uma mulher exuberante.

Vinha carregada de malas e, posso jurar, jamais havia visto mulher tão bela em minha vida. (...). À pureza dos traços - o nariz, apenas, era

${ }^{3}$ CARDOSO, 2000, p. 112.

${ }^{4}$ CARDOSO, 2000, p. 91. 
ligeiramente aquilino - unia-se uma atmosfera estranha e tormentosa, que a tornavam logo à primeira vista um ser irresistível. ${ }^{5}$

Sobre a impressão de sua chegada à Chácara, quem descreve é a governanta Betty:

Creio que fui a primeira pessoa a vê-la, desde que desceu do carro e - oh! - jamais, jamais poderei esquecer a impressão que me causou. Não foi apenas um simples movimento de admiração, pois já havia deparado com muitas outras mulheres belas em minha vida. Mas nenhuma como esta conseguiu misturar ao meu sentimento de pasmo essa leve ponta de angústia, essa ligeira falta de ar que, mais do que a certeza de me achar ante uma mulher extraordinariamente bela, forçoume a reconhecer que se tratava também de uma presença (...). ${ }^{6}$

Além desses, há outros depoimentos de personagens da Crônica que se verifica o fascínio que Nina despertava nos membros daquele lar e nos próprios moradores da redondeza, como foi possível perceber à chegada de Nina na estação, "fazendo os próprios Meneses recuarem para um discreto segundo plano", 7 como descreve o farmacêutico.

Representando a mulher "caseira" da Chácara, Ana era cunhada de Nina. Casada com Demétrio Meneses, por conveniência entre famílias, desde moça morava ali, pois fora preparada desde cedo para ser esposa, seguindo o que rege a tradição oriental, de que "sinhazinhas" deviam ser "dadas em casamento ainda meninas a homens às vezes mais velhos que seus próprios pais". Além do hábito "de se revestirem de mantilhas ou de xales. O de armarem as senhoras o cabelo em penteados altos (...)". ${ }^{8}$

Assim representada, Ana é o extremo oposto de Nina, o que causa nela, a princípio, uma confusão de sentimentos, visível na primeira confissão que faz ao Padre Justino, quando declara sentir a presença do Diabo, por ocasião da vinda de Nina à Chácara:

${ }^{5}$ CARDOSO, 2000, p. 92.

${ }^{6}$ CARDOSO, 2000, p. 60. (Grifo meu).

${ }^{7}$ CARDOSO, 2000, p. 92.

${ }^{8}$ FREYRE, 1998, p. 458. 
Padre, acredito ter visto a presença tangível do diabo e, mais do que isto, ter alimentado com o meu silêncio, e a minha aquiescência portanto, a destruição latente da casa e da família que há muitos anos são as minhas (...).

Não sei precisar quando, nem em que minuto exato a transformação se deu - o fato é que ela se achava entre nós, talvez chegada há pouco, não sei, mas já atuando dentro da época febril que então vivíamos. ${ }^{9}$

A presença "diabólica” de Nina na família é assim caracterizada por Ana porque a cunhada despertava interesses até em Demétrio, conhecido por seu humor hostil e fechado. Mesmo nunca tendo amado o esposo, como confessa, Ana sentia ciúmes de Nina por ela ser o que nunca teve a oportunidade: uma mulher desejada, com roupas elegantes, coloridas, cabelos cuidados e pele perfumada.

Ah, como era bela, como era diferente de mim. Tudo na sua pessoa parecia animado e brilhante. Quando caminhava, fazia girar no espaço uma aura de interesse e de simpatia - exatamente o oposto do que sucedia a mim, ser opaco, pesadamente colocado entre as coisas, sem nenhum dom de calor ou de comunicação. ${ }^{10}$

Nina pode ser considerada como a representação da cidade no ambiente de decadência pelo qual habitava a família patriarcal dos Meneses, além da forte tendência ocidental no Brasil. Ela trazia àquele lugar em ruínas o novo, o colorido e o também fugaz da cidade. "Não sei, não sei - murmurou - Essas velhas famílias sempre guardam um ranço no fundo delas. Creio que não suportam o que eu represento: uma vida nova, uma paisagem diferente". ${ }^{11}$ Essa característica do urbano era visível, principalmente, pela indumentária dela, com "vestidos bonitos e caros, com enfeites que brilhavam à luz do sol". ${ }^{12}$ Além disso, Nina usava chapéus da última moda (europeização, nas palavras de Gilberto Freyre) ao invés dos xales (orientalização).

\footnotetext{
${ }^{9}$ CARDOSO, 2000, p. 103 e 106.

${ }^{10}$ CARDOSO, 2000, p. 107.

${ }^{11}$ Palavras de Nina. In: CARDOSO, 2000, p. 66.

${ }^{12}$ CARDOSO, 2000, p. 315.
} 
De fato, Nina era uma presença desde que ali se instalou. Um exemplo disso é que, mesmo depois de ter decidido viver com o marido no Pavilhão (uma construção antiga e aos fundos do casarão, para livrar-se da inveja e especulações a respeito de seus hábitos singulares para aqueles), Nina ainda estava na casa através dos comentários e das espreitas feitas, principalmente, por Ana:

Mas a verdade é que eu não a perdia de vista, acompanhava-a como uma sombra, espreitava-a pelas frestas, através das portas entreabertas, junto às vidraças descidas, de qualquer modo que pudesse vislumbrar sua silhueta estranha e magnética. ${ }^{13}$

Esse magnetismo provocado por Nina corrobora para o que já estava em ruínas na casa: o relacionamento entre os membros da família e o status social que os Meneses ainda tentavam manter perante a sociedade de Vila Velha; ou seja, o próprio ideal de família e sociedade é posto em questão.

$\mathrm{O}$ escandalizante e devasso da cidade é vivificado em Nina e faz sucumbir as bases de uma instituição que já está enfraquecida das leis fixas, estáveis e seculares, porque os indivíduos que as constituem já sentem a indiferença, o isolamento e a desintegração provocados pela mudança econômico-social do século XIX. Na modernidade, encontram-se elementos heterogêneos, como o tempo. É possível, numa grande cidade, sair de um prédio do século XVIII e entrar em outro do século XVI. "Quem entra numa cidade, sentese como numa tessitura de sonhos, onde o evento de hoje se junta ao mais remoto" ${ }^{14}$ Ou seja, o que antes parecia definitivo, a partir da modernidade tornou-se efêmero, indiferente, como uma planta às manifestaçôes do tempo.

Oposta à Ana, ou seja, oposta ao que representam os Meneses, Nina, agente de fragmentação da cidade, é capaz das maiores ousadias, visível em seu ultraje e atitudes. Num momento crítico do romance, de enfrentamento entre Ana e Nina, é possível perceber esse cenário antagônico. O diálogo inicia com Nina questionando Ana:

- Veio para matar-me... por que não o faz agora?

Respondi:

- Não posso.

\footnotetext{
${ }^{13}$ CARDOSO, 2000, p. 108.

${ }^{14}$ BENJAMIN, 2000, p. 209.
} 
Então ela investiu contra mim, e sem dúvida percebendo que eu tudo vira do seu crime e do seu sofrimento, ergueu o punho como se me ameaçasse: - Não pode, não pode, e eu vou-lhe dizer por quê. Porque é uma Meneses, porque o sangue dos Meneses, que é o seu, contaminou-a como de uma doença. Porque você não quebraria nunca a quietude desta casa com um tiro - a paz, a sacrossanta paz desta família - nem cometeria um incesto, nem um assassinato, nada que manchasse a honra que eles reclamam.

- Não é verdade - murmurei.

(...) Ah, ela estava com a razão, não havia dúvida - e de que modo humilhante para mim! Ali, com o revólver ainda nas mãos, só poderia reconhecer que me vencera - a mim, a todos nós escravos de um hábito, de uma verdade, de um ensinamento que não ousamos destruir e nem ultrapassar. ${ }^{15}$

Compreende-se, conclusivamente, o que a presença de Nina realmente causava naquele lar: mais do que uma oposição, a ciência de que há outros (e principalmente novos) hábitos, costumes e estilos de vida, diferentes - e por isso mesmo - escandalizantes para quem se acostuma com uma forma de viver e pensar.

O diálogo entre Ana e Padre Justino vêm ao encontro do que se disse até agora. No diálogo, é visível essa nova concepção das coisas, das mudanças que estavam ocorrendo no Brasil (no início do século XIX):

- Se inferno existe, Padre Justino, é aqui nesta casa. O senhor nem pode conceber em que desordem...

(...)

- Eu sei (...). Ei-lo: não é de hoje que o diabo tomou conta desta Chácara. (...)

- O diabo, minha filha, não é como você imagina. Não significa a desordem, mas a certeza e a calma.

(...)

- Que é que você imagina como uma casa dominada pelo poder do mal? (...) É uma construção assim, firme nos seus alicerces, segura de suas tradiçôes, consciente da responsabilidade do seu nome. Não é a tradição que se arraiga nela, mas a tradição transformada no único escudo da verdade.

\footnotetext{
${ }^{15}$ CARDOSO, 2000, p. 264. (Grifos meus).
} 
(...) Ah, minha amiga, pode acreditar em mim, nada existe de mais diabólico do que a certeza. (...) Tudo o que é firme e positivo é uma negação do amor. ${ }^{16}$

\section{A presença cultural do Oriente e do Ocidente na Chácara de Vila Velha}

O livro, Crônica da casa assassinada, traz, ao seu início (exceto na segunda edição), o mapa da Chácara dos Meneses (ver Anexo I), feito pelo próprio autor, que concebia plasticamente, também, os cenários de suas peças, as características de suas personagens e dos locais onde se desenrolava a ação dos romances, pois após ter sofrido um derrame cerebral, em 1962, que o incapacitou de escrever, Lúcio Cardoso começou a dedicar-se à pintura e ao desenho. Tal mapa pode ser comparado com desenhos de sobrados feitos por Lula Cardoso Ayres e Carlos Leão, muito utilizados nas edições de Sobrados e mucambos, de Gilberto Freyre (ver anexo II). Parece que Lúcio Cardoso procurou, até nos detalhes, fazer com que a ficção propusesse um aspecto realista.

Os ambientes internos e externos dos casarões e sobrados patriarcais denotam influências de sua colonização e posterior abordagem às culturas européias. Como exemplo, através dos hábitos da família Meneses, pode-se encontrar um peculiar. Em muitos momentos da trama de Lúcio Cardoso, descreve-se que os Meneses deitavam-se em uma rede para descansar, como no trecho a seguir, retirado do Diário de Betty (I): "Horas mais tarde, indo à varanda a fim de sacudir a toalha, encontrei a patroa ${ }^{17}$ estendida numa rede. Seu aspecto era de inteiro aniquilamento."

Hábito peculiar porque, conforme descreve Gilberto Freyre, contrastava com os dos burgueses de sobrado, "tão europeus nos estilos de vida". Em Minas, os fazendeiros ricos eram quem dormiam em redes. Essas observações, Freyre encontra em Saint-Hilaire e Mawe, que escreveram sobre os hábitos dos mineiros, "Porque foi em Minas que se desenvolveram, então, no Brasil, os estilos de vida e os padrôes de conforto físico que deliciaram europeus como Mawe e SaintHilaire". ${ }^{18}$

\footnotetext{
${ }^{16}$ CARDOSO, 2000, p. 254-255. (Grifos meus).

17 "Patroa" era como Betty chamava Nina. In: CARDOSO, 2000, p. 65.

${ }^{18}$ FREYRE, 1990, p. 331.
} 
Tal hábito - de deitar-se à rede - em todas as vezes que aparece no romance é sempre relacionado como um costume dos Meneses de descansarem após alguma refeição, como pode se observar nesse outro trecho, da Primeira Confissão de Ana: "Meu marido costumava dormir logo após o almoço, quer fosse numa rede propositadamente estendida na varanda, quer em nossa grande cama de jacarandá que a penumbra do quarto acalentava”. ${ }^{19}$

Os móveis de jacarandá são predominantes na casa dos Meneses, em quase todos os ambientes. Pela citação acima, vimos que era de jacarandá a cama do casal Demétrio e Ana, e a mesma madeira também estava presente em outros móveis da sala:

(...) Enquanto dava essas explicaçôes, conduziu-me à sala, e mais uma vez, com a curiosidade e o prazer que sempre haviam me animado, e como se assistisse à demonstração de um espetáculo mágico, ia revendo aquele ambiente tão característico de família, com seus pesados móveis de vinhático ou de jacarandá, de qualidade antiga, e que denunciavam um passado ilustre, geraçôes de Meneses talvez mais singelos e mais calmos (...). Mesmo assim era fácil perceber o que haviam sido, esses nobres da roça, com seus cristais que brilhavam mansamente na sombra, suas pratas semi-empoeiradas que atestavam o esplendor esvanecido, seus marfins e suas opalinas - ah, respirava-se ali conforto, não havia dúvida, mas era apenas uma sobrevivência de coisas idas. Dir-se-ia, ante esse mundo que se ia desagregando, que um mal oculto o roía, como um tumor latente em suas entranhas.

Dona Nina achava-se estendida num divã (era uma espreguiçadeira esburacada, e sobre ele haviam estendido um xale vermelho) e naquele momento, com a testa molhada de suor, estava visivelmente pálida. ${ }^{20}$

Essa descrição minuciosa da sala é feita pelo farmacêutico, que fora chamado à Chácara para examinar Nina, que até então não sabia que estava grávida. É possível perceber como os "pesados móveis de vinhático ou de jacarandá", nas próprias palavras do narrador, simbolizam o "peso" e a força da tradição na família patriarcal; além de denotarem a tendência oriental dos

\footnotetext{
${ }^{19}$ CARDOSO, 1963, p. 93.

${ }^{20}$ CARDOSO, 1963, p. 113. (Grifos meus).
} 
móveis; sem contar o xale de cor vibrante, quente e forte (vermelho). Já a prata e a opalina são tendências ocidentais de nossa cultura brasileira. ${ }^{21}$

Há determinados lugares na casa aptos a certas ocasiōes. O escritório, por exemplo, é o lugar de reuniōes, de assuntos importantes: "Que Valdo e Demétrio conversavam no escritório - é o lugar onde se reúnem, quando há alguma coisa importante a tratar". ${ }^{22} \mathrm{O}$ oratório simbolizava a religião, a fé, o isolamento, por isso localizava-se ao fundo dos quartos — "encaminhei-me ao oratório que ficava ao fundo do quarto e retirei de dentro a lamparina que iluminava permanentemente a imagem de Nossa Senhora das Graças". ${ }^{23}$

$\mathrm{O}$ jardim era o ambiente externo e apto a quem desejasse escapar do peso que abatia aquela tradicional família. Era no jardim que Nina encontrava-se, primeiro com Alberto, e posteriormente com André, seus amantes; também era no jardim que na geração anterior a matriarca dos Meneses, Dona Malvina, confessava-se com Padre Justino:

Era no fundo, lado direito do Pavilhão, onde antigamente havia uma clareira limitada por quatro estátuas representando as Estações. Só o Verão ainda se fazia ver de pé, e a parte inferior da Primavera, em cujo interior, como de dentro de um vaso, crescia uma vigorosa samambaia dominando os bordos partidos. ${ }^{24}$

Quem faz a descrição da topografia do local é Ana, em sua Primeira Confissão. Logo após essa descrição, Ana deixa claro que lá era local que quase ninguém pisava, mas onde Nina se dirigia para encontrar Alberto. Naquela época, Nina recém tinha se mudado, junto com seu esposo Valdo, para o Pavilhão,

(...) uma construção de madeira que existia no fundo do jardim, antigamente pintada de verde, há muito sem cor definida, estigmatizada pelo tempo, gasta pelas chuvas, com lances de mofo e estrias criadas pela umidade, o que lhe emprestava um caráter desagradável e sujo. ${ }^{25}$

\footnotetext{
${ }^{21}$ Sobre esta questão ver FREYRE, 1998, p. 466.

${ }^{22}$ CARDOSO, 1963, p.70.

${ }^{23}$ CARDOSO, 1963, p. 249.

${ }^{24}$ CARDOSO, 1963, p. 94.

${ }^{25}$ CARDOSO, 2000, p. 93.
} 
Continuando a Confissão, Ana esclarece a inveja que a corroia:

Naquele tempo eu a invejei, por ficar livre de nós, da Chácara. (...) Mas, coisa curiosa, sozinha agora no prédio grande da Chácara, eu não tinha mais sossego, imaginando o que estaria fazendo minha cunhada, quais seriam seus propósitos e pensamentos. ${ }^{26}$

Assim, Ana aproveitava os momentos em que Demétrio relaxava na rede e dirigia-se ao Jardim com o intuito de, entre a vegetação, permanecer escondida e vigiar cada passo de Nina.

$\mathrm{O}$ auge da representação das influências orientais e ocidentais na cultura brasileira, percebidas por Gilberto Freyre em Sobrados e mucambos e vistas aqui sob a ótica ficcional de Lúcio Cardoso, está na figura da governanta Betty, única entre os empregados da Chácara a ter sua "voz ouvida" na obra Crônica da casa assassinada. Inglesa de origem, Betty é impecável em seus serviços, além de ter uma vida culta, o que deixa transparecer no seguinte trecho, do Diário de André (V):

Depois deste entusiasmo, decidi mudar todos os meus hábitos. Comecei por ajuntar os livros que Betty me emprestava - umas histórias ingênuas, sempre de autores ingleses - e fui entregar tudo a ela. Estava no quarto e espanava justamente sua pequena biblioteca, empilhando cuidadosamente os livros forrados com papel marrom. ${ }^{27}$

A partir do início do século XIX o Brasil começa a receber influências européias nos modos de vida, principalmente na cultura e economia, que passam a ser essencialmente industriais. Para os burgueses da época, o Brasil tinha que perder, o quanto antes, a influência oriental que recebera dos jesuítas e asiáticos, e começar a adquirir

(...) as formas, as cores e os gestos dominantes no Ocidente perfeitamente civilizado. E para eles o Ocidente perfeitamente civilizado eram a Inglaterra e a França. Principalmente a Inglaterra. Donde o sentido sociológico da frase que desde os princípios do século XIX se generalizou no Brasil: 'para inglês ver'. ${ }^{28}$

\footnotetext{
${ }^{26}$ CARDOSO, 2000, p. 93.

${ }^{27}$ CARDOSO, 1963, p. 222. (Grifos meus).

${ }^{28}$ FREYRE, 1998, p. 427.
} 
Betty estabelecera-se na casa dos Meneses para ensinar a língua inglesa ao ainda menino Timóteo, ${ }^{29}$ mas depois permanece exercendo as funções de governanta da família; além disso, "todo o sistema de objetos que compõe o interior da mansão senhorial assinalam a presença dos britânicos". ${ }^{30}$ Exemplo disso, entre outros já citados, é o piano: "Foi então que Demétrio, tocado não sei por que malévola inspiração (...) encaminhou-se para o fundo da sala e abriu o piano que fora de sua mãe, grande pianista nos seus tempos de moça" ${ }^{31}$

Outro momento que fica visível a influência ocidental na mansão dos Meneses é quando eles se reúnem para um jantar especial por ocasião do segundo retorno de Nina à Chácara. Na Quarta Confissão de Ana, ela descreve esse momento:

Talvez por ordem de Valdo, que desejaria festejar o regresso, ou dela própria, quem sabe, haviam desenterrado da velha arca o aparelho de porcelana que viera da Europa e que ostentava entre festóes de folhas douradas, o $\mathrm{M}$ do sobrenome familiar. (...) Demétrio mal provara $o$ vinho, enquanto Valdo e Nina abusavam francamente dele. ${ }^{32}$

O desaparecimento de características orientais na arquitetura doméstica, nos modos de vida e de cultura no Brasil, marcaria "a vitória decisiva do Ocidente sobre o Oriente na luta entre culturas ou civilizações a que o Brasil vinha servindo há anos de campo", 33 mas tal "desassombramento" foi difícil e muitos brasileiros, principalmente as mulheres, resistiram ao impacto da produção industrial européia.

Aliás a vitória do Ocidente sobre o Oriente no Brasil foi menos fácil e mais lenta, em certos meios, ou com relação a certos estilos de vida, do que parece à primeira vista ter sido (...) $\mathrm{Na}$ verdade só em relação com os sobrados ricos do Rio de Janeiro parece ter sido fulminante. ${ }^{34}$

\footnotetext{
${ }^{29}$ Ver capítulo 46 da Crônica da casa assassinada. In: CARDOSO, 1963, p. 369.

${ }^{30}$ ROSA E SILVA, 1995, p. 59.

${ }^{31}$ CARDOSO, 1963, p. 332.

${ }^{32}$ CARDOSO, 1963, p. 332. (Grifos meus).

${ }^{33}$ FREYRE, 1998, p. 429.

${ }^{34}$ FREYRE, 1998, p. 451.
} 
Tal cenário pode ser representado mais uma vez por Nina que, coincidentemente ou não, é carioca, simboliza a presença (violenta - erótica) da ocidentalização no meio rural, patriarcal e tradicional dos Meneses; e esses, especialmente Ana, representam a tradição, o antigo, a orientalização.

Para Baudrillard, essas simbologias de que se reveste a casa, com seus móveis, cômodos e adereços "é uma imagem fiel das estruturas familiais e sociais de uma época". Seres e objetos estão ligados na significação, "extraindo os objetos de tal conluio uma densidade, um valor afetivo que se convencionou chamar sua "presença". 35

\section{Os autores, a narrativa e suas obras}

A narrativa de Lúcio Cardoso, em Crônica da casa assassinada, é inovadora por ser constituída através de escritas em diários, confissões e testemunhos que costuram a história de uma tradicional família mineira, os Meneses. É um romance não-linear, como se o leitor estivesse diante de uma caixa velha, sendo que dentro dela há muitos papéis antigos, contendo a história de uma família.

Diante da caixa, o leitor vai tirando esses papéis, degustando da leitura, mas percebendo que cada papel é escrito por pessoas diferentes, ora é um membro dos Meneses quem desabafa, ora a governanta da família, ora o médico ou o farmacêutico. Há até confissão de um padre entre os papéis! Lendo-os, é possível perceber que um fato tem mais de uma maneira de ser contado.

Esse recurso narrativo foi empregado por Lúcio Cardoso antes mesmo da elaboração do romance Crônica da casa assassinada (1956). Na trilogia intitulada $O$ mundo sem Deus, composta pelas novelas Inácio (1944), O enfeitiçado (1954) e Baltazar (incompleto), todas ambientadas no Rio de Janeiro, Lúcio Cardoso colocou em cena as mesmas personagens que contam a história empregando a primeira pessoa do discurso. Enquanto em Inácio o narrador é Rogério, em $O$ enfeitiçado quem narra é Inácio, e em Baltazar a narração é feita por Adélia. Todas esses personagens estão presentes nas três novelas.

${ }^{35}$ TURRER. In: BRANDÃO, 1998, p. 112. 
É possível compreender (...) como a elaboração desta trilogia, calcada no uso de diferentes vozes narrativas, parece ter servido ao escritor como um exercício para o uso do foco narrativo múltiplo que adotaria na Crônica da casa assassinada. A alternância de narradores em $O$ mundo sem Deus já prenunciava o processo que, desenvolvido no livro de 1959, permitiria ao ficcionista a construção das mais variadas versões a respeito dos acontecimentos e das motivações das personagens, confrontando o leitor com visões conflitantes e até excludentes sobre um mesmo fato. ${ }^{36}$

Cássia dos Santos (2001) reitera que essa prévia do uso do múltiplo foco narrativo, empregado por Lúcio na trilogia, encontra opinião favorável também em Mario Carelli, em seu livro Corcel de fogo.

Quanto à escrita de Gilberto Freyre, pode-se afirmar que é calcada em rememorações particulares dele próprio. No prefácio à sexta edição de Sobrados e mucambos, Freyre afirma ter crescido "ouvindo histórias da negrinha Isabel e aprendendo palavrōes com o malungo Severino e ouvindo da negra velha Felicidade (...) suas experiências dos dias antigos" ${ }^{37}$

Freyre escreveu livros célebres, como Casa grande e senzala, sobre a formação da sociedade brasileira e sobre as influências de hábitos, costumes e estilos de vida que demarcaram a cultura do país. Foi pautando-se sobre documentos históricos, recortes de jornal e, sobretudo, histórias orais, que Freyre mapeou um Brasil desde sua origem como nação caracterizada, especialmente, pelo engenho, até os dias modernos, marcados pela soberania industrial.

Em suas obras, Freyre tenta reconstituir alguns aspectos íntimos, que demarcaram (e que, por ventura, até hoje marcam) a história social brasileira, em especial a familiar, e assim o faz de forma cronológica.

O centro de interesse para o nosso estudo de choques entre raças, entre culturas, entre idades, entre cores, entre os dois sexos, não é nenhum campo sensacional de batalha. (...). O centro de interesse para o nosso estudo desses antagonismos e das acomodaçôes que lhes atenuaram as durezas, continua a ser a casa. ${ }^{38}$

\footnotetext{
${ }^{36}$ SANTOS, 2001, p. 126.

${ }^{37}$ FREYRE, 1998, p. XXX.

${ }^{38}$ FREYRE, 1998, p. XLI.
} 
Para isso, Freyre faz uso da rememorização de suas experiências, além de ter pesquisado sobre o tema em jornais da época. Sua narrativa é embasada, indiscutivelmente, em fatos reais, mesmo na sua auto-intitulada seminovela Dona Sinhá e o filho padre (1964). Nesta obra híbrida, Freyre afirma que quase tudo foi inventado, pois reuniu características de vários indivíduos para formar as personagens, "considerados na pessoa imaginária de um tipo como que sociologicamente ideal; e um tanto, também, de história: história de uma época de transição na vida brasileira e que foi a dos avós, já adultos, e a dos pais, ainda crianças, do autor". ${ }^{39}$ Ou seja, mesmo a invenção de Freyre parte de um "real" datado historicamente.

Benjamin, em $O$ narrador, afirma que "A experiência que passa de pessoa a pessoa é a fonte a que recorreram todos os narradores". ${ }^{40} \mathrm{Na}$ modernidade, conforme o mesmo autor, a arte de narrar está cada vez mais em extinção porque o que se narra não é experiência, é uma informação que vem estampada num jornal e, na maioria das vezes, é um fato distante, longe de qualquer familiaridade com o leitor.

O romance também tem contribuído com a morte da narrativa, diz Benjamin, pois, enquanto a narrativa procede da tradição oral, o romance está muito ligado ao livro, a um ato isolado do narrador em "falar exemplarmente sobre suas preocupações mais importantes (...) Escrever um romance significa, na descrição de uma vida humana, levar o incomensurável a seus últimos limites". ${ }^{41}$ Freyre, então, aproxima-se dessa imagem melancólica de narrador que Benjamin pinta, um "narrador que retira da experiência o que ele conta: sua própria experiência ou a relatada pelos outros. E incorpora as coisas narradas à experiência dos seus ouvintes". ${ }^{42}$

Para Benjamin, "O grande narrador tem sempre suas raízes no povo, principalmente nas camadas artesanais". ${ }^{43}$ Neste contexto Lúcio Cardoso considerava-se "tão romancista quanto um sapateiro é fabricante de sapatos" ${ }^{44}$

\footnotetext{
${ }^{39}$ FREYRE, 1971, p. 144.

${ }^{40}$ BENJAMIN, 1996, p. 198.

${ }^{41}$ BENJAMIN, 1996, p. 198.

42 BENJAMIN, 1996, p. 201.

${ }^{43}$ BENJAMIN, 1996, p. 214.

${ }^{44}$ SANTOS, 2001, p. 132.
} 
e dizia, ainda, não acreditar no romance sociológico ou em Virginia Woolf, mas não sabia explicar suas crenças. Para ele era "como se tentasse dizer por que tenho mãos ou por que escrevo". ${ }^{45}$

Romancista assumido, Lúcio Cardoso representa, em Crônica da casa assassinada, por meio de personagens, ambientes e objetos "sentimentos envenenados que corroem o espírito desse país, que o torna inerte e sem viço para o futuro", ou seja, a Crônica seria "o mito de um país agonizante". ${ }^{46}$

Outro mito seria o papel do autor, na literatura. Para Barthes, "O autor é uma personagem moderna" em quem buscamos a explicação da obra, "como se, através da alegoria mais ou menos transparente da ficção, fosse sempre afinal a voz de uma só e mesma pessoa, o autor, a entregar a sua 'confidência"'. ${ }^{47}$ Assim, para Barthes, a unidade do texto encontra sentido no leitor; é ele quem vai reunir, em um único campo, todos os traços múltiplos de que é constituído o escrito.

\section{Palavras finais}

As mesmas presenças nos sobrados e casas-grandes de Gilberto Freyre são encontradas na Chácara de Vila Velha, em especial a abertura das residências às novidades do mundo exterior.

A rotina, os hábitos e os modos de viver das famílias patriarcais foram lenta, mas solidamente perturbados, ocasionando estranhamento e, muitas vezes, antipatia ao novo. Nina, como agente de fora, em Crônica da casa assassinada, trouxe o ruído da cidade ao silêncio do campo, assim como os mascates, as boceteiras e quitandeiras adentraram os casarões para trazerem, de fora, doces, quitutes e demais mercadorias às senhoras dos sobrados.

Inevitável e irreversível mudança, as casas foram ficando cada vez mais (entre)abertas, compondo o cenário cada vez mais citadino que se arquitetava e, sobretudo, marcando a desintegração do patriarcado em nossa sociedade e a conseqüente reorganização da mesma, porém, sobre outras bases, as quais, ainda hoje, vêm ganhando novas nuances.

\footnotetext{
${ }^{45}$ SANTOS, 2001, p. 134.

${ }^{46}$ ROSA E SILVA, 1995, p. 24.

${ }^{47}$ BARTHES, 1988, p. 66.
} 


\section{Referências Bibliográficas}

BARTHES, Roland. A morte do autor. In: O rumor da língua. São Paulo: Brasiliense, 1988.

BARTHES, Roland. Da leitura. In: O rumor da língua. São Paulo: Brasiliense, 1988.

BATAILLE, Georges. O erotismo. Trad. Cláudia Fares. São Paulo: ARX, 2004.

BENJAMIN, Walter. Magia e técnica, arte e politica. 10. reimpressão. São Paulo: Brasiliense, 1996.

BRANDÃO, Ruth Silviano (Org.). Lúcio Cardoso: a travessia da escrita. Belo Horizonte, Ed. UFMG, 1998.

CARDOSO, Lúcio. Crônica da casa assassinada. 2. ed. Rio de Janeiro: Letras e Artes, 1963.

2000.

. Crônica da casa assassinada. 3. ed. Rio de Janeiro: Civilização Brasileira,

CARELLI, Mario. Corcel de fogo: vida e obra de Lúcio Cardoso (1912-1968). Trad. Júlio Castañon Guimarães. Rio de Janeiro, Guanabara, 1988.

FREYRE, Gilberto. Sobrados e mucambos. 10. ed. Rio de Janeiro: Record, 1998. Sagarana).

. Dona Sinhá e o filho padre. São Paulo: José Olympio, 1971. (Coleção

ROSA e SILVA, Enaura Quixabeira. A alegoria da ruina. Curitiba: HD Livros, 1995.

SANTOS, Cássia dos. Polêmica e controvérsia em Lúcio Cardoso. São Paulo: Mercado de Letras, 2001.

TURRER, Daisy. Sob um sol que uniformiza tudo. In: BRANDÃO, Ruth Silviano (Org.). Lúcio Cardoso: a travessia da escrita. Belo Horizonte, Ed. UFMG, 1998, p. 111-119. 


\section{Resumo}

Este artigo pretende perceber as representaçōes possíveis que se podem encontrar da obra de Gilberto Freyre, Sobrados e Mucambos, em Crônica da Casa Assassinada, de Lúcio Cardoso, uma vez que ambas abordam o mesmo viés: a decadência do sistema patriarcal e a conseqüente ascensão do urbano, datados do início do século XIX. A narrativa de Gilberto Freyre é um recorte real da sociedade brasileira daquele período, calcada em rememoraçôes particulares dele próprio; em Lúcio Cardoso a narrativa ficcional envolve o ambiente de uma típica família tradicional mineira que resiste às influências externas, concretizadas, especialmente, na personagem Nina; e à inevitável perda da supremacia patriarcal.

\section{Abstract}

This article intends to realize the possible representations that can be found in the work of Gilberto Freyre, Sobrados e mucambos, and in Crônica da casa assassinada, of Lúcio Cardoso, once that both board the same slant: the decadence of the patriarchal system and the consequent ascent of the urbane one, when they dated from the beginning of the century XIX. The narrative of Gilberto Freyre is a real cutting out of the Brazilian society of that period, based on particular remembrances of own him; in Lúcio Cardoso to narrative ficcional wraps the environment of a typical traditional mining family that resists the extern, made real influences, specially, in the character Nina; and to the inevitable loss of the patriarchal supremacy. 


\section{ANEXO I}

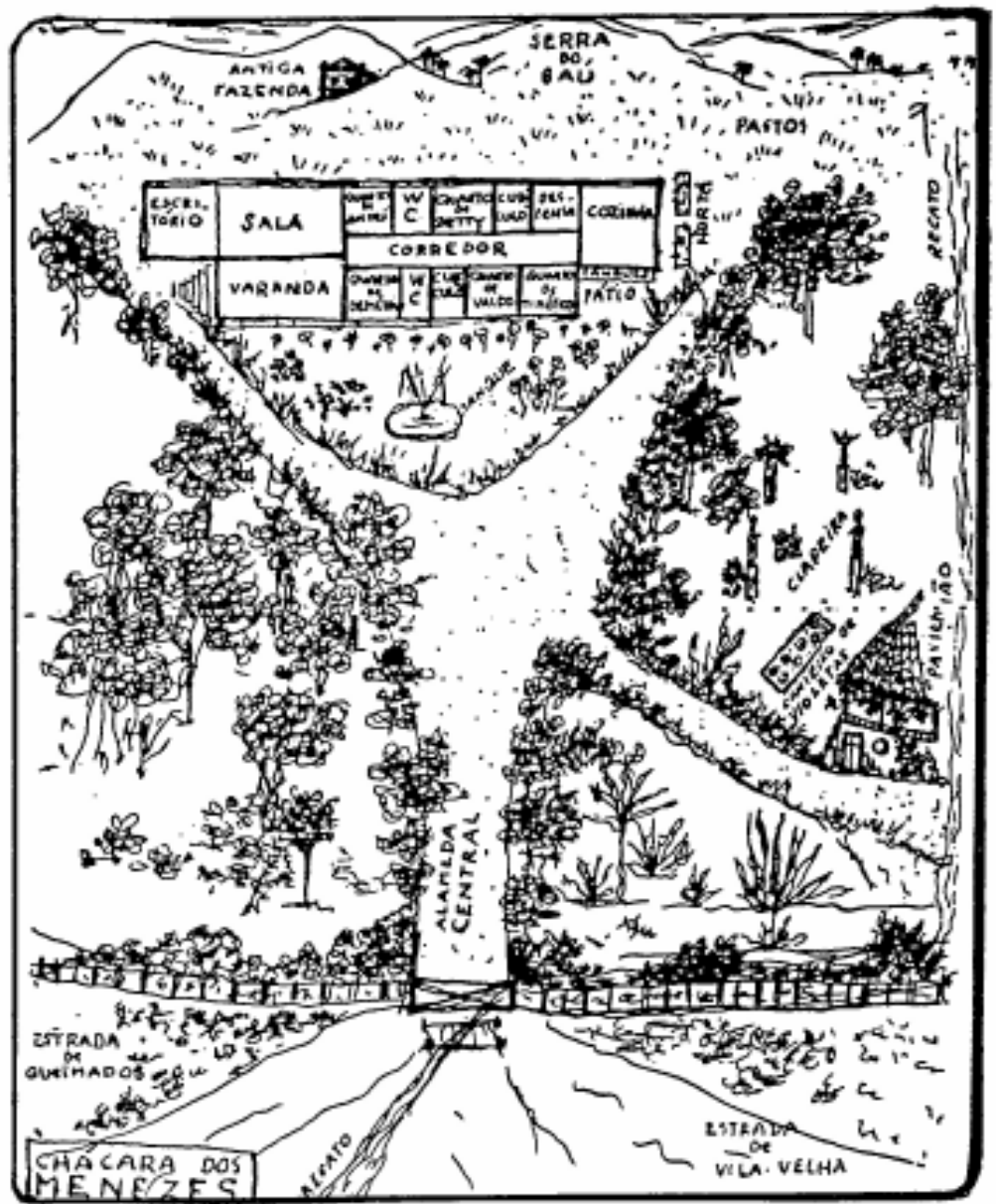

Planta da chácara dos Meneses

${ }^{48}$ In: CARDOSO, 2000, p, 18. 


\section{ANEXO II}

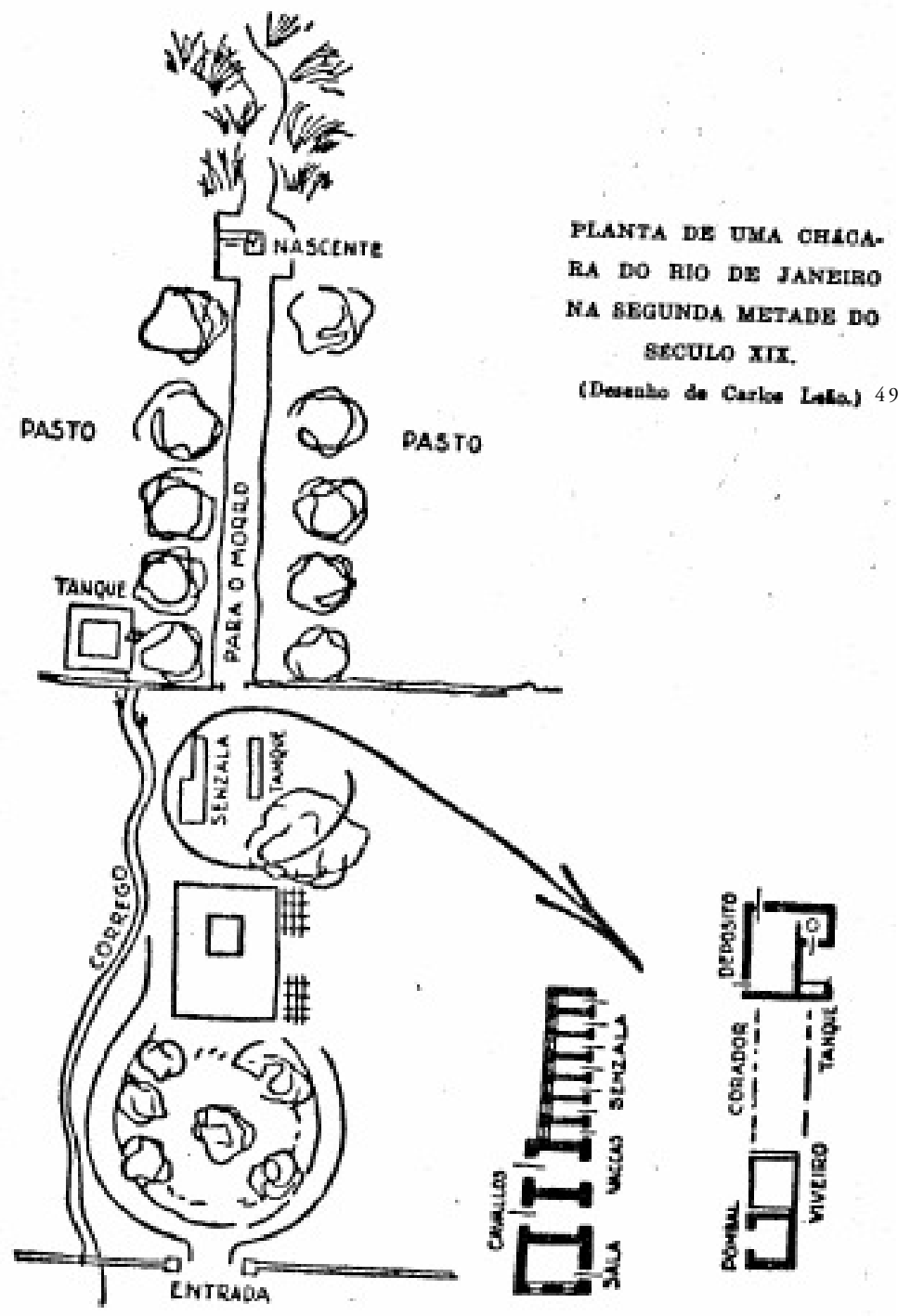

${ }^{49}$ In: FREYRE, 1998, p. 189. 